1 Delhi, India

2 London, UK

indiastoryagency@gmail.com Cite this as: BMJ 2021;375:n2409 http://dx.doi.org/10.1136/bmj.n2409 Published: 08 October 2021

\title{
Myanmar doctors are under fire from the military and covid-19
}

\section{Myanmar's doctors are under violent attack from its occupying government as the covid-19 pandemic rages. Geetanjali Krishna and Sally Howard report}

\author{
Geetanjali Krishna, , Sally Howard,
}

Even in a country with a history of politicising healthcare, the six months since the Tatmadaw armed forces seized power in Myanmar on 1 February have been particularly bloody for the nation's healthcare professionals.

On 28 March, during a strike against the military dictatorship in the city of Monywa, a nurse was fatally shot in the head. On 21 April, two private hospitals in Bhamo, Kachin state, had their licences to treat patients revoked. This came after Myanmar armed forces said they would revoke the licence of any health facility that employs health workers who participate in the civil disobedience movement resisting the junta's rule, and would prosecute those that provide assistance to health workers. On 8 May, in northern Kachin, a doctor was arrested and fatally shot in the head while passing a military base, and in June, two covid-19 treatment centres in Sagaing were destroyed by military shelling.

In this, the third military coup in the last 60 years, Myanmar has become one of the most dangerous places on earth for healthcare workers, with 240 attacks this year; nearly half of the 508 attacks tracked globally by the World Health Organization. A report in July by UK Aid, USAID, and Manchester University's Researching the Impact of Attacks on Healthcare $^{1}$ found that there had been 190 arrests of healthcare workers, 25 killings of healthcare workers, and 55 military occupations of hospitals in the five months to 1 July.

The junta's violent reprisals against healthcare stem from a belief that medics are the principal exponents of the civil disobedience movement, says Thomas Andrews, UN special rapporteur on Myanmar. "Yes, doctors care deeply about what has happened to their country and see the impacts first hand, but you can't exaggerate the role one profession plays in what is a widespread movement," he told The BMJ. The arrest and harassment of doctors while treating patients in the Myanmar protests have been condemned by the World Medical Association. ${ }^{2}$

Rather than acknowledging its attacks on medical workers, the military is instead accusing them of genocide for not treating patients. "They are killing people in cold blood. If this is not genocide, what shall I call it?” military spokesperson Major General Zaw Min Tun said during a live broadcast on national television on 9 April.

Ironically, it is this stance that is driving some medics to the civil disobedience movement in the first place. Lamin Maungmaung is a 22 year old fourth year medical student whose studies have stopped and who is now resisting the junta. "Our senior doctors as well as professors are hiding or fleeing at the moment or else they would get abducted and tortured to death, or detained in prison with substandard healthcare," he told The BMJ.

Although some, like Maungmaung, are striking in protest at their persecution, many doctors are continuing to give primary care voluntarily at township level, and midwives continue to deliver maternal care, at risk of reprisals, says Mitchell Sangma, Médecins Sans Frontières (MSF) medical coordinator for Myanmar.

\section{A creaking system faces covid-19}

The crackdown on healthcare is hitting an already vulnerable system at a critical time. Even before the takeover, Myanmar had just 0.67 doctors per 10000 people in 2018, which is considerably lower than the global average of 15.6 in 2017, according to the World Bank.

Nearly one million children in Myanmar have been denied routine vaccinations amid the political upheaval of the military's coup d'état, while MSF told The $B M J$ that it is now administering antiretroviral drugs to $4000 \mathrm{HIV}$ patients displaced from the public healthcare system. Securing vaccinations for children has been particularly difficult in Myanmar's remote border regions, where military offensives against ethnic armies and the armed wing of the government in exile, the People's Defence Force, have displaced an estimated 230000 residents since the coup.

Against this turbulent backdrop, the covid-19 pandemic is raging in Myanmar as the delta variant spreads through Asia. Reliable data are difficult to find, but Johns Hopkins University lists a seven day average of 2698 cases a day as of 23 August. ${ }^{3}$

In April, when 23 year old activist August Khant (name changed on request) tested positive for covid-19 he was unable to seek medical help from public services as there was a warrant out for his arrest; going to private hospitals was also difficult. "The doctors, nurses, and medical workers who are helping to fight covid-19 in the frontline are accused as criminals," he said in a Twitter message to The $B M J$. "I had no option but to buy expensive medicine from a pharmacy, where there were long lines of people."

Khant says that people in this queue were discussing deaths that had occurred because of a crippling shortage of oxygen in Myanmar. "I realised that if I needed oxygen, I'd have to line up at the charity [services provided by non-governmental organisations active in Myanmar, such as MSF] to get it and risk getting beaten up by the military junta," 
he said. In July, Myanmar's military leader, Senior General Min Aung Hlaing, ordered oxygen plants to work at full capacity, including converting industrial oxygen for the needs of patients.

There is also a growing health crisis in Myanmar's overcrowded prisons. In July, Nyan Win, a spokesperson for ousted Myanmar leader Aung San Suu Kyi's political party, died after being infected with SARS-CoV-2 in Yangon's Insein prison. An estimated 6000 people have been arbitrarily detained in Myanmar since the coup. ${ }^{4}$

A source communicating with an imprisoned medic (who did not want to be named) told The BMJ that cells in Myanmar's prisons are dangerously overcrowded, there is no mask wearing or basic hygiene, and symptoms of covid-19 in these settings are rife. According to them, only one of Myanmar's 96 prisons and labour camps, ${ }^{5}$ Insein prison, has sufficient equipment and resources to treat coronavirus cases. NUG Myanmar, the deposed government now operating in exile, has called for the immediate and unconditional release of all political prisoners, in response to the rising number of coronavirus infections and deaths in prisons.

The true extent of the pandemic is also unknown since testing for covid-19 has plummeted in Myanmar. According to Oxford University's Our World in Data, the positive test rate is $25.6 \%$ compared with $1.1 \%$ in May. ${ }^{6}$ The case fatality rate rose from $2 \%$ to $4 \%$ in the period from February to August, and of the 15287 deaths that have occurred in the country, around two-thirds have been in this third wave. This compares with a $1.9 \%$ positivity rate in neighbouring India (as of 28 August), now emerging from its own brutal second wave of covid-19.

Moreover, there is widespread mistrust of vaccines delivered by the military junta. The doctor who led the country's vaccination programme, Htar Htar Lin, was arrested and charged with high treason in June, and many citizens, including doctors, have become distrustful of being vaccinated at junta controlled hospitals for fear of arrest, as well as suspicion over what they might be administered. ${ }^{7}$ Zaw Wai Soe, Myanmar's minister for health in exile, told The BMJ that refusing vaccines is seen by citizens as a public gesture of civil disobedience until Aung San Suu Kyi, the imprisoned former state counsellor of Myanmar, is released.

NUG Myanmar fears that $40 \%$ of the population-around 25 million people-could be infected in Myanmar's vicious third wave. "This will result in a death rate of 400000 or 800000 if we don't act now," says Zaw Wai Soe.

\section{A fragile healthcare system cracks}

On 21 July, NUG Myanmar formed a covid-19 taskforce in collaboration with independent health organisations run by the country's ethnic minorities "to prevent, mitigate and control the spread of covid-19 pandemic in Myanmar.” NUG announced that it had acquired six million doses of vaccines and would soon start two vaccination programmes: one to be carried out in ethnic areas by ethnic armed groups and the other administered by third party organisations, such as the United Nations and the United Nations Children's Fund.

Zaw Wai Soe says that by working at the township level, rather than state and division level (which are militarily controlled), the acting government and humanitarian agencies can reach $20 \%$ of the adult population with vaccines by the end of 2021. MSF's Mitchell Sangma endorses this strategy, observing that by working at a local township level, as opposed to the bigger cities, the rollout has largely been able to stay clear of military patrols. Telemedicine programmes are plugging some of the gaps left by a collapsed healthcare system, with five telemedicine channels (including the website doxy.me and the instant messaging app Telegram), many staffed by local doctors in the diaspora, offering 5000 consultations a day for treatment of covid-19 and other conditions. However, the military recently disrupted one of these. Medical student volunteers affiliated with the civil disobedience movement have also been helping patients with covid-19 to get oxygen by connecting them to charities and international aid organisations.

The UN's Thomas Andrews, who presented a report to the UN Human Rights Council in Geneva in September, ${ }^{8}$ says that abysmal vaccination levels and non-existent covid-19 treatment facilities might see Myanmar becoming a super spreader state, if the international community does not intervene.

"With the attack on the healthcare system, high [covid-19] positivity rates, and a third of humanity living in countries bordering Myanmar, mutations that give rise to dangerous covid variants are a worrying possibility,” he warns.

\section{A Myanmar medic's testimony}

After the military coup in February 2021, Pha Yaung (name changed on request), a doctor practising in a private hospital in Yangon, was part of the White Coat protests against the militia.

Even as the medical professionals gathered to protest, the militia used smoke bombs and rubber bullets to disperse them. "We'd assembled peacefully, but the militia gave no warning," he says. "I can still hear the screams of my colleagues who got hurt."

Yaung managed to find refuge in a monastery. Since then, he has experienced multiple attacks and raids. "One time, the junta raided our hospital and took away our surgical scalpels and the petrol stored for powering our generator," he recounts. "The next day, newspapers reported that they had confiscated weapons and Molotov cocktails." He remembers another time when the militia came at midnight, asking to look at patient records.

Over the past few months, Yaung has seen several colleagues arrested from clinics and hospitals with the military run State Administrative Council targeting doctors and other health workers for their leading role in the nationwide civil disobedience movement. Yaung says that in Yangon a medic responded to what he had been told was a covid-19 emergency, only to be arrested by the militia who had lured him there.

Yaung's family fears they may not see him again when he leaves the house each day in his white coat. They plead with him to stop practising medicine. "But I think it's my duty to continue," he says. "The junta has intimidated, imprisoned, and even killed so many colleagues. I have to fill the void they have left behind."

Competing interests: None declared.

Provenance and peer review: Commissioned; not externally peer reviewed.

Aid UK. RIAH, USAID. Violence against or obstruction of health care in Myanmar. http://insecurityinsight.org/wp-content/uploads/2021/08/Violence-Against-Health-Care-in-Myanmar-FebruaryJuly-2021-August-update.pdf.

World Medical Association. Harassment and arrest of doctors in Myanmar condemned by physician leaders. https://www.wma.net/news-post/harassment-and-arrest-of-doctors-in-myanmar-condemned-by-physician-leaders.

Covid-19 data repository by the Center for Systems Science and Engineering (CSSE) at Johns Hopkins University. https://github.com/CSSEGISandData/COVID-19.

4 United Nations Human Rights Council. Statement by Thomas H Andrews, UN special rapporteur on the situation of human rights in Myanmar, at the United Nations Human Rights Council. 11 Mar 2021. https://www.ohchr.org/EN/NewsEvents/Pages/DisplayNews.as-

px?NewsID=27283\&LangID=E.

World Prison Brief. Myanmar (formerly Burma). https://www.prisonstudies.org/country/myanmarformerly-burma.

Our World in Data. Myanmar: coronavirus pandemic country profile. https://ourworldindata.org/coronavirus/country/myanmar.

Physicians for Human Rights. PHR condemns Myanmar military's arrest of former head of covid-19 vaccine rollout. 12 Jun 2021. https://phr.org/news/phr-condemns-myanmar-militarys-arrest-offormer-head-of-covid-19-vaccine-roll-out. 
8 UN Human Rights Council. Special rapporteur on the situation of human rights in Myanmar to the Human Rights Council: there is a compelling case that the military junta in Myanmar is committing crimes against humanity. Sep 2021. https://reliefweb.int/report/myanmar/specialrapporteur-situation-human-rights-myanmar-human-rights-council-there.

This article is made freely available for use in accordance with BMJ's website terms and conditions for the duration of the covid-19 pandemic or until otherwise determined by BMJ. You may use, download and print the article for any lawful, non-commercial purpose (including text and data mining) provided that all copyright notices and trade marks are retained. 